بررسى اثر استفاده از كابل در كنترل آبشستگى اطراف گروه يايههاى يل در رودخانه

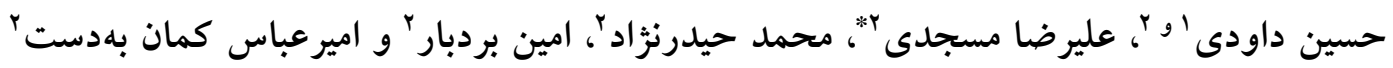

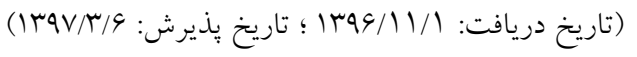

حكيده

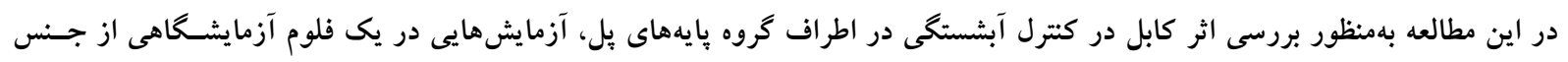

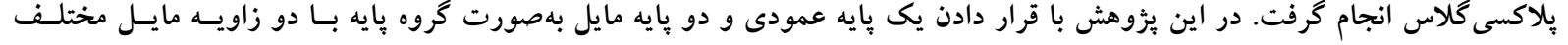

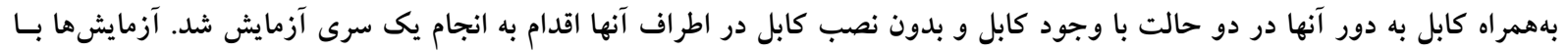

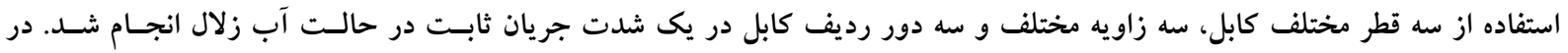

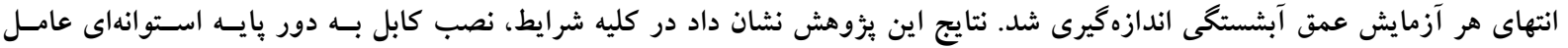

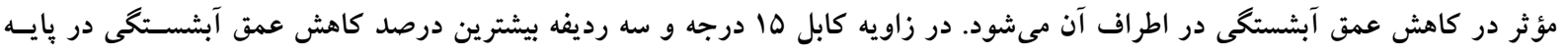

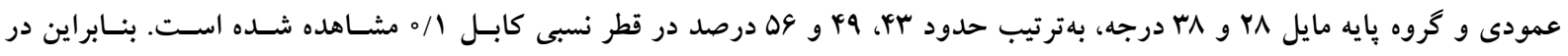

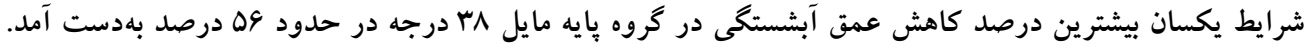

وازههاى كليدى: كابل، عمق آبشستخى، گروه بِايه بِل، رسوبات

1. گروه علوم و مهندسى آب، يرديس علوم تحقيقات خوزستان، دانشخاه آزاد اسلامى، اهواز، ايران

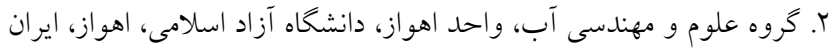

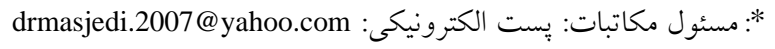


خصوص تأثير توأم طوق و كابـل بــر عمـق آبشستـكى اطـراف

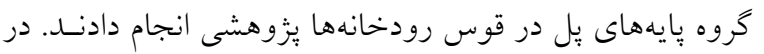

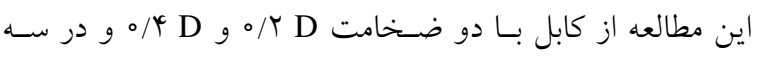

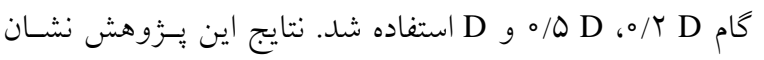

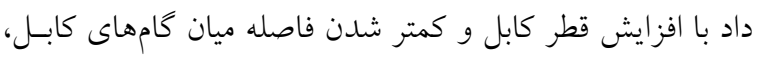

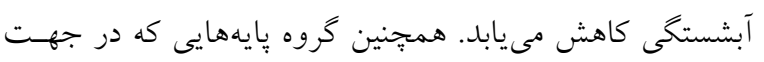

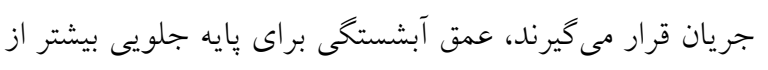

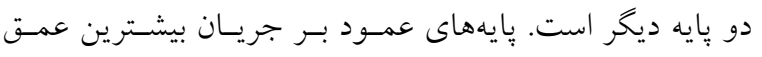

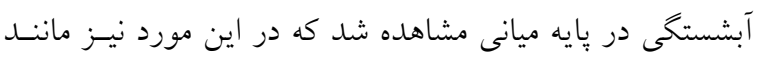

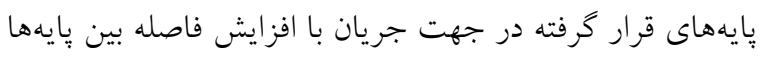
عمق آبشستخى كم مى شود. استفاده توأم طوق و كابل بيشـترين

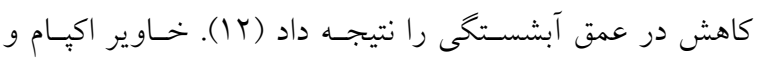
مزومدار در مورد اثر بيجشش كابـل دور بايسههاى بــل مطالعساتى

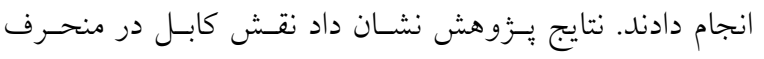

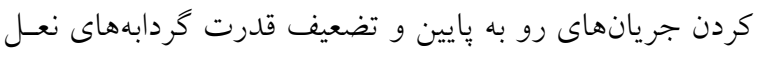

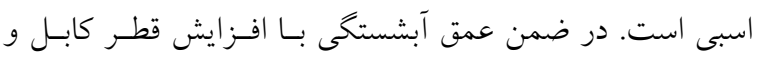

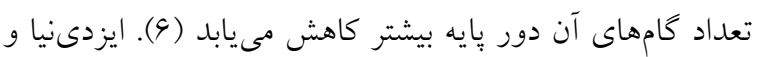

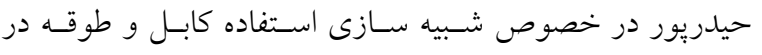

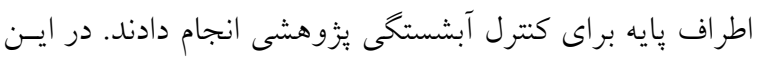
ئزوهش در مسير مستقيم با سه قطر مختلف ז، أ و و ميلى متر و

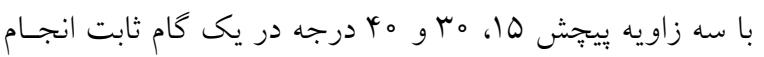

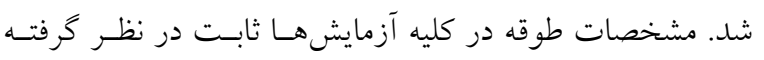

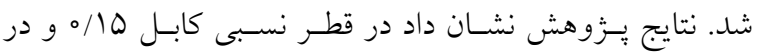

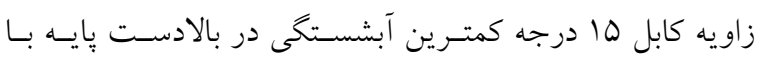
وجود طوقه در حدود سمه درصد بهدست آمد (ه) (ه).

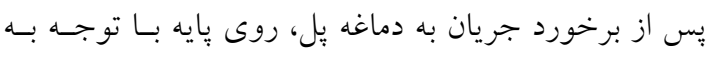

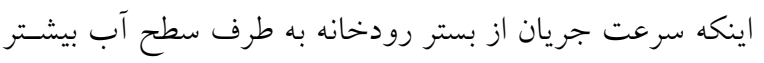
مىشود، فشار بيشترى نيز در ترازهـاى بـالاتر روى بايسه ايجـاد

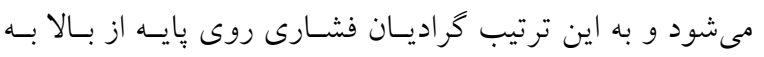

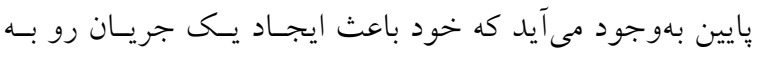

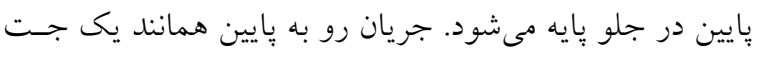

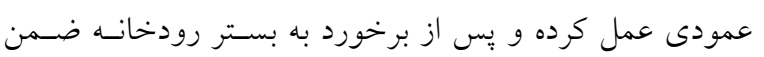

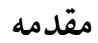

اخر بِايه استوانهاى بهطور عمودى در مسير جريـان قـرار گرفتـهـ

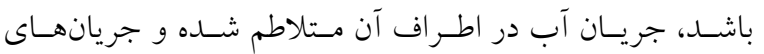

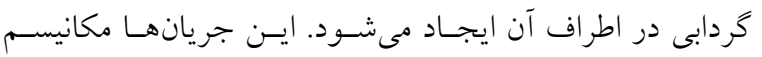

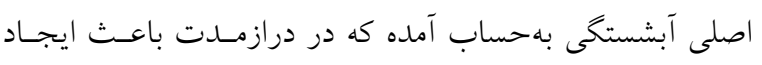

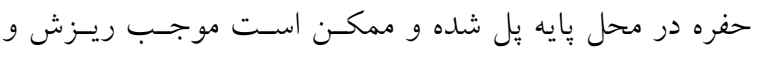

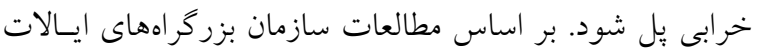

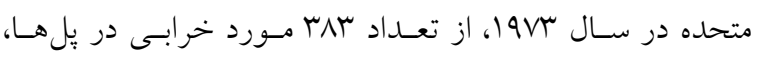

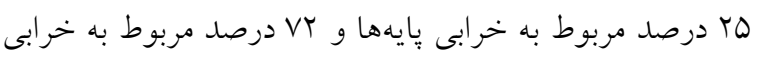

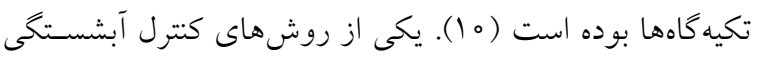

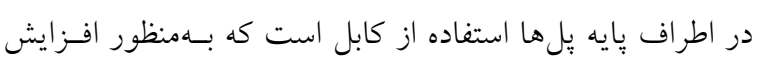

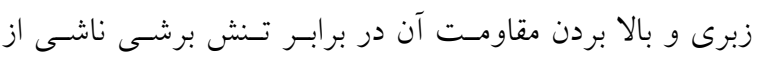

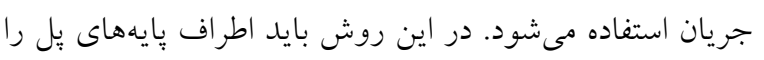

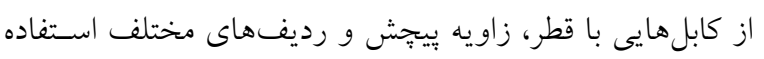

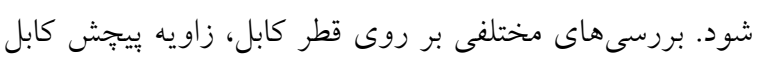

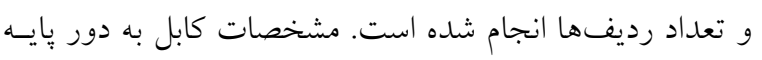

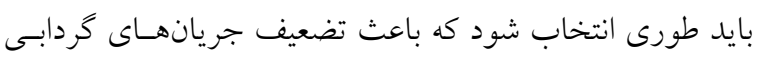

$$
\text { در اطراف بايه شود. }
$$

روش اسـتفاده از كابـل توسط دئ دى و همكــاران در سـال

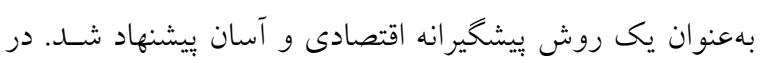

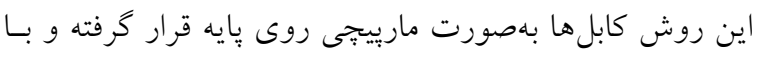

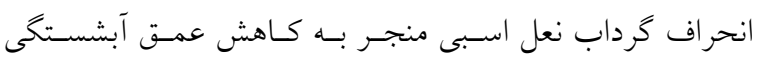

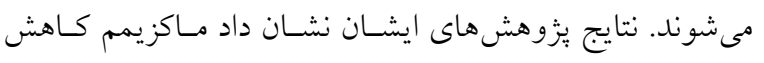

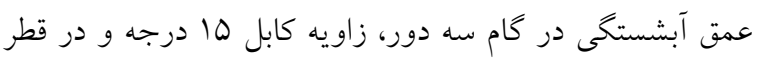

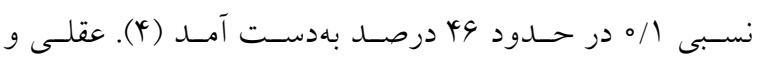
همكاران يُزوهشى در خصوص اثر توأم طوق و كابل روى عمق آنق

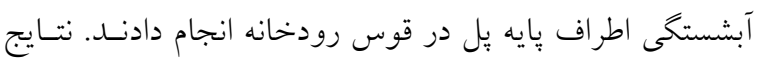

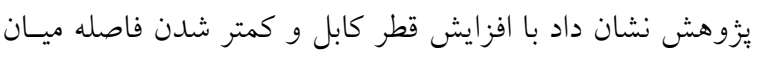

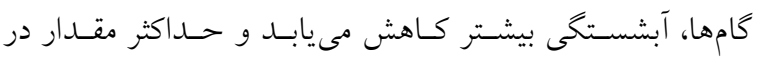

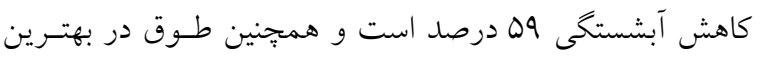

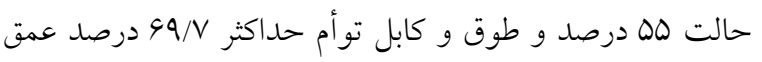

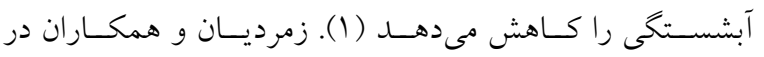




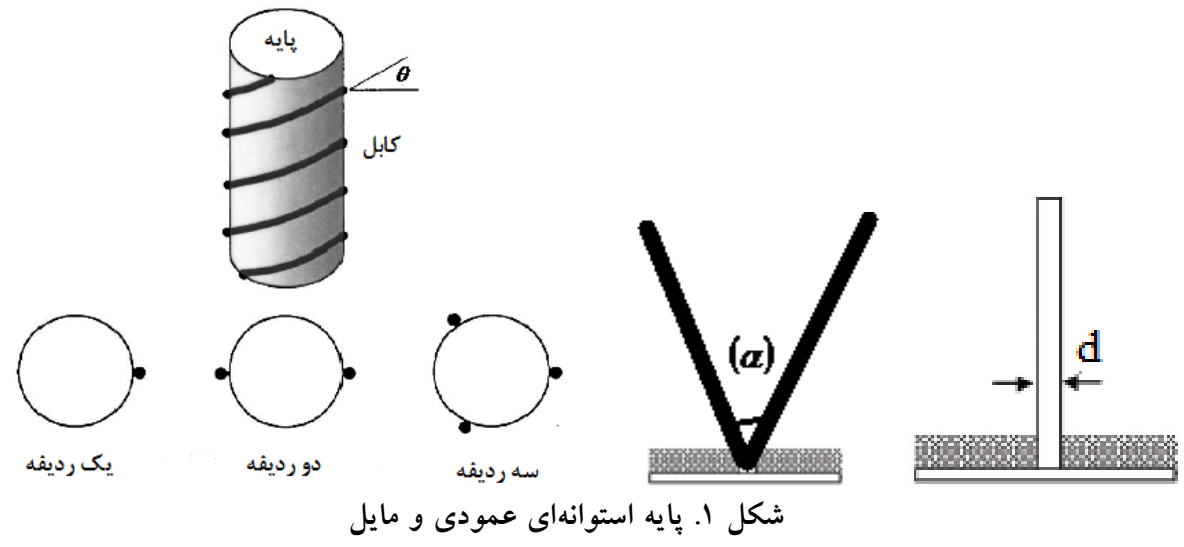

حالتهـا)، ds max عمـق آبشسـتخى مـاكزيمم در بِايـه بــدون

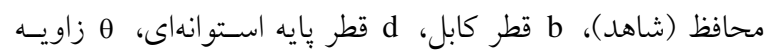

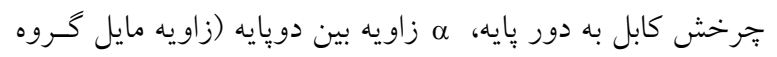

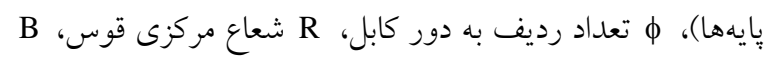

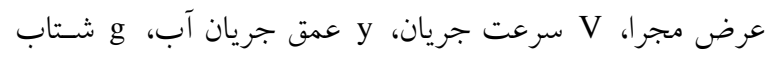

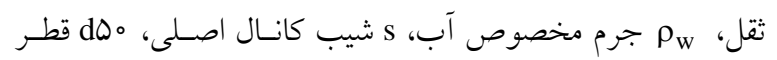

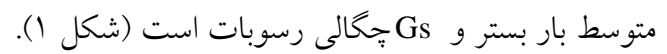

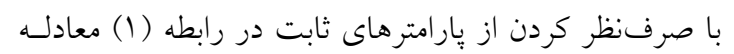

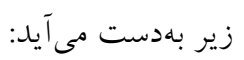

$\mathrm{fr}(\mathrm{ds}, \mathrm{ds} \max , \mathrm{b}, \mathrm{d}, \alpha, \varphi)=。$

با استفاده از تئورى باكينخهام رابطه (Y) بهصورت زير بدون بعد

$\mathrm{f} r\left(\frac{\mathrm{ds}}{\mathrm{dsmax}}, \frac{\mathrm{b}}{\mathrm{d}}, \alpha, \varphi\right)=。$

$\frac{\mathrm{ds}}{\mathrm{ds} \max }=\mathrm{f}\left(\frac{\mathrm{b}}{\mathrm{d}}, \alpha, \varphi\right)$

در رابطه (r و \&l)، ds/ds max عمق آبشستخى نس-بى و b/d قطر نسبى كابل است. در كليه آزمايشها با توجسه بـه آشـفتخى جريان در اطراف آبشكن، جريان از نسوع مستلاطم بـوده و عسدد رينولدز حذف شد.

امروزه با بيشرفت فناورى طراحى و ساخت سازهها، شـاهد ساخت يل ها با اشكال گوناگونى بوده كه از جمله آنها مىتـوان به بِلها با گرووه بايه مايل اشاره كرد. فرايند آبشستخى در گـروه
حفر بستر به هر طرف يراكنـده مى شـود ( إ). مقـدارى از ايسن جريان كه به سمت بالا باز گشت مى كند، در برخورد بـه جريـان عمومى رودخانه، مجبور به حركـت در جهـت جريسان شـده و

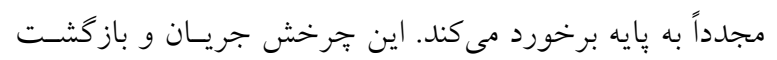

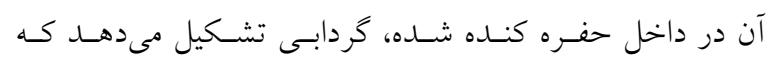
بهتدريج در دو طرف يايه، امتداد يافته و شكل شبيه نعـل اسـب يديد مى آورد كه به آن خـرداب نعـل اسـبى مى گوينـد. تشـكيل

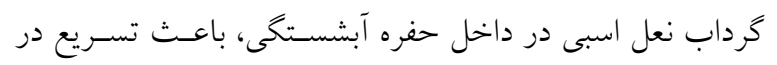

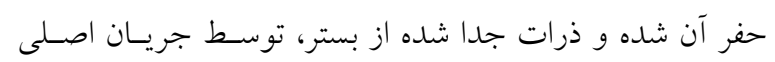
رودخانه به ياييندست حمل مىشوند (r). در اثر جدايى جريـان در كنارههـاى بايسه نيـز گردابهـايى تشكيل مىشوند كه محور آنها عمود بر بستر رودخانسه اسـت و

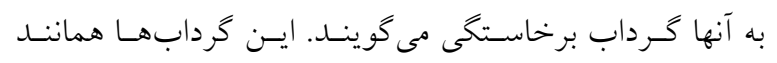
كردبـاد ذرات بسـتر را جــا كــده و در معسرض جريسان قـرار

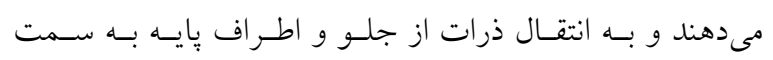
ياييندست كمك مى كنند. حفر كودال آبشستخى توسط كـرداب نعل اسبى آنقدر ادامه مى يابد تا حجم آب درون حفره آبشستخى

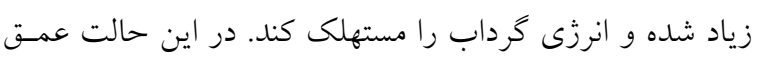

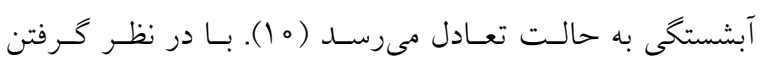

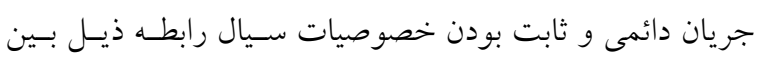
يارامترهاى مؤثر بر عمق آبشستخى در حالت تعادل برقرار است: $\mathrm{f}_{1}$ (ds, ds max, b, d, $\left.\alpha, \varphi, \mathrm{R}, \mathrm{B}, \mathrm{V}, \mathrm{y}, \mathrm{g}, \rho_{\mathrm{w}}, \mathrm{S}, \mathrm{d} \diamond \circ, \mathrm{Gs}\right)$ در رابطه (1s (1) عمق آبشستـى در بايـه بـا محسافظ (در كليـه 

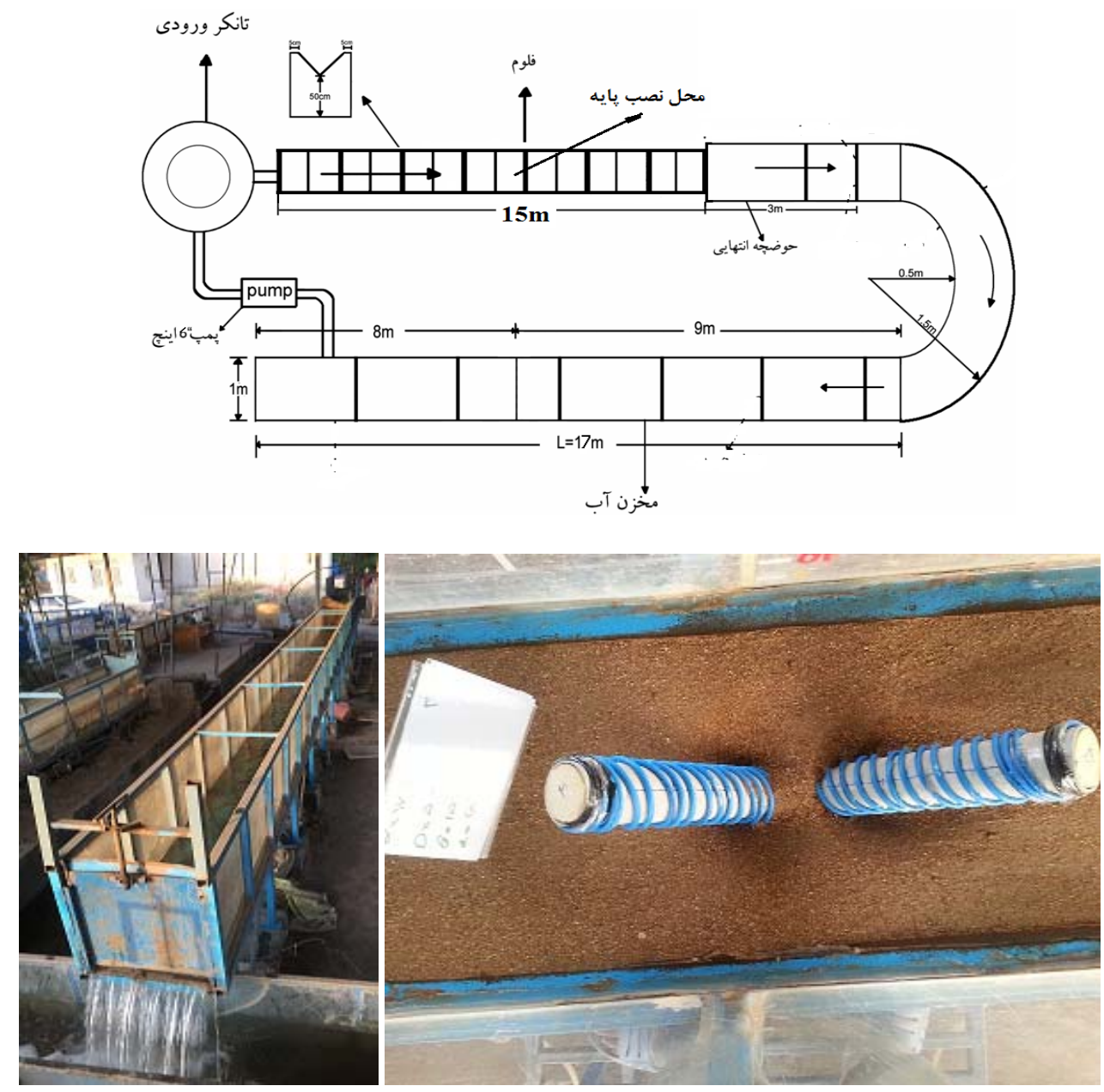

شكل r. نمايى از فلوم آزمايشخاهى

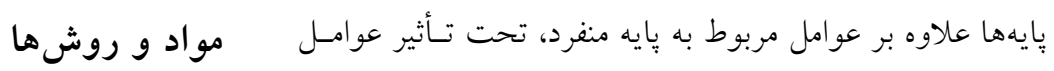

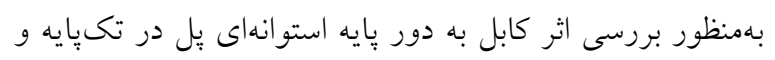

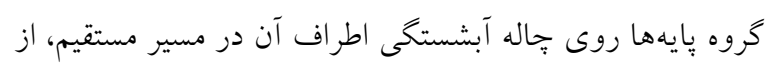

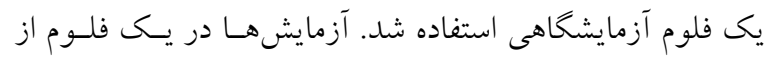
جنس بِلكسى گلاس قوسى شكل با مقطع مستطيلى، با طول 10

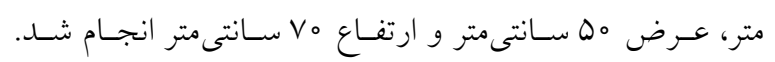

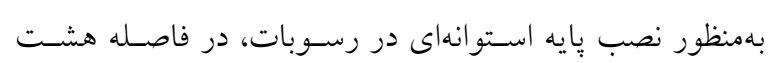
مترى از ابتداى فلوم، يكى مخزن به طول يكى متسر و ارتفــاع 10

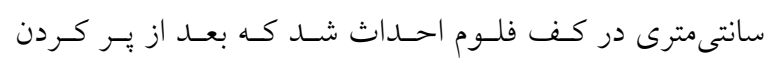
رسوبات در آن، سطح تراز كف فلوم و رسوبات يكسان خواهند شد (شكل r r).

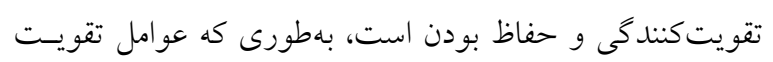

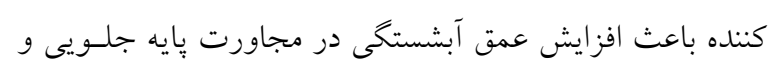

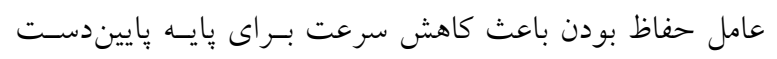

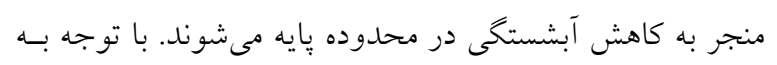

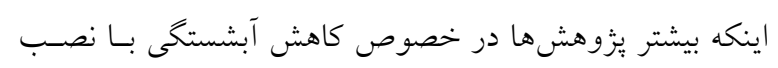

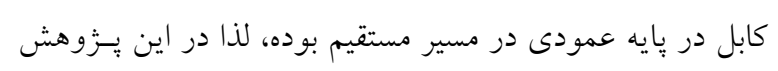

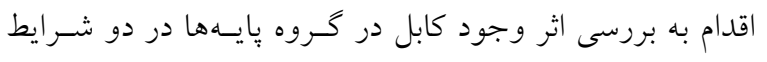

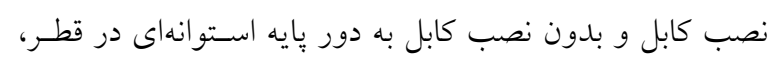

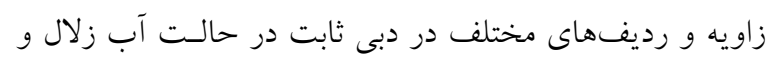
مقايسه آن با تكيايه عمودى شده است. 


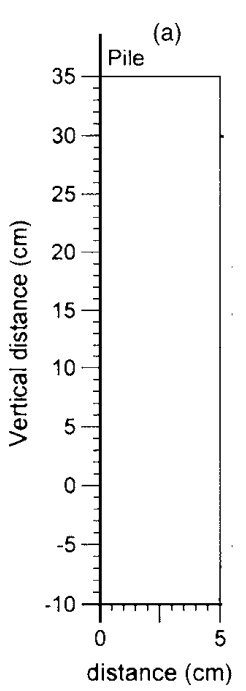

(b)

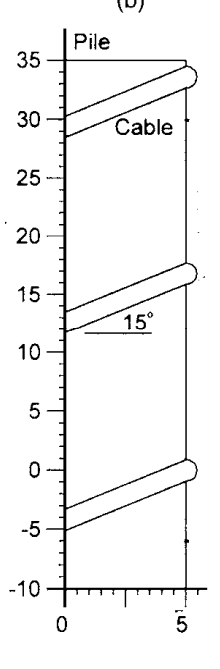

(c)

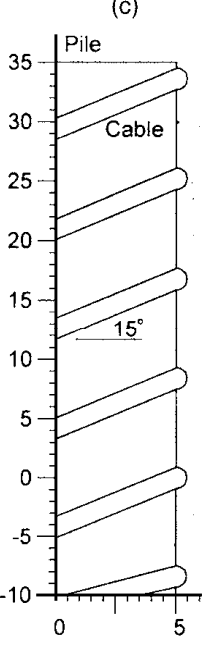

(d)

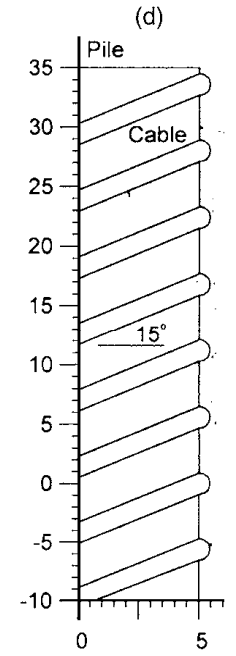

شكل r. نصب كابل به دور پايه استوانهاى: a پايه عمودى بدون كابل، b) پايه يك رديفه، c) پايه دو رديفه، d) پايه سه رديفه

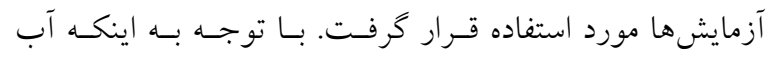

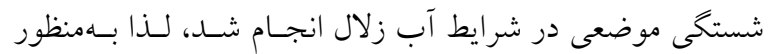

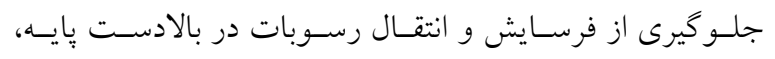
سرعت متوسط جريان بايد كمتر از سرعت بحرانس (u <

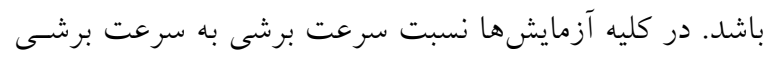

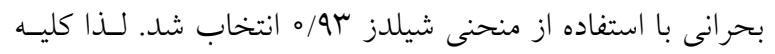

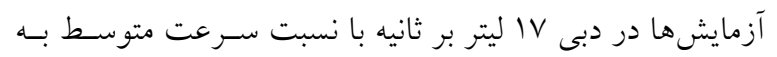

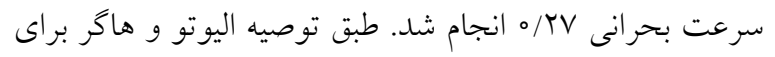

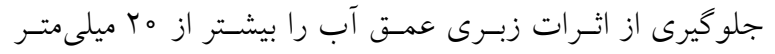

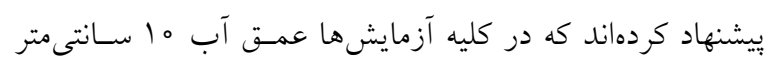

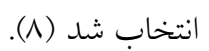
بهمنظور تعيين زمان تعادل آزمايشها، يك آزمايش طـولانى لته

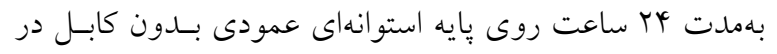

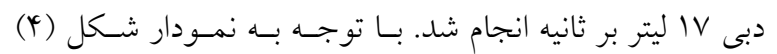

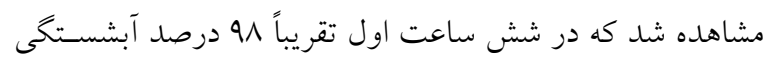
رخ مىدهد. عمق آبشستكى در اين آزمايشها بر اسـاس معيسار

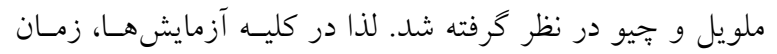
تعادل شش ساعت انتخاب شد (V)

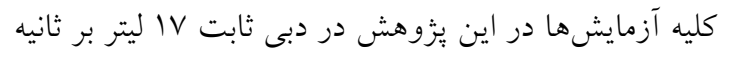

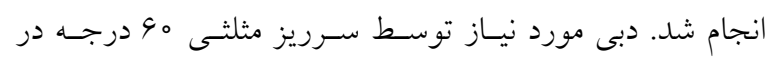

براى حذف تأثير ديوارههاى كانال بر آبشستـى موضسعى بايسه،

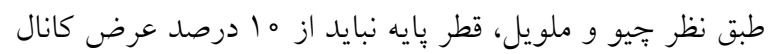

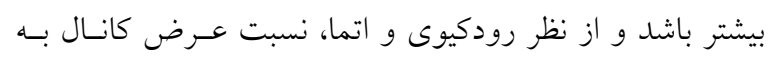

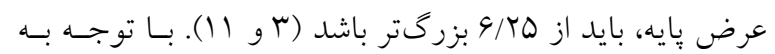

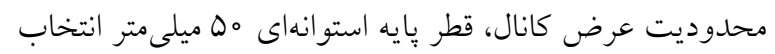

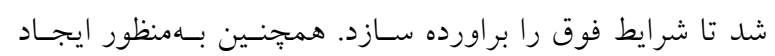

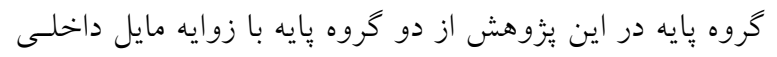

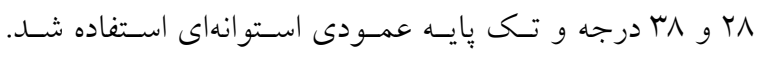
بامنظور بررسى اثر نصب كابل در اطراف بايه اسـتوانهاى كـروه

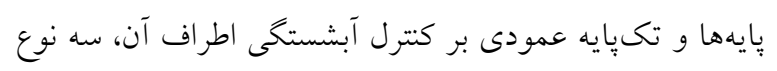

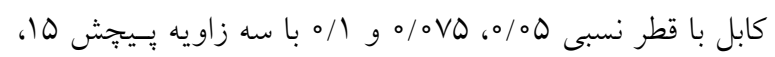
مبا و ها درجه در سه رديف يك، دو و سه دور در نظر كرفتسه شد (شكل r). به توصيه راودكيوى و اتما براى جلو كيرى از تشكيل رييـل،

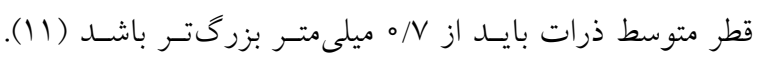

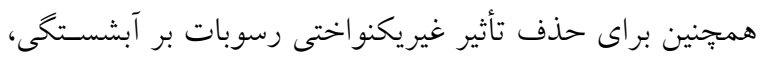

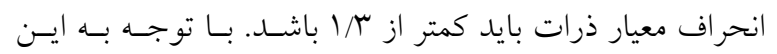
موارد يكى لايه از ماسه طبيعى رودخانهاى با قطر متوسط معـادل

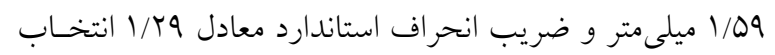

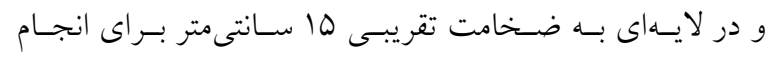


نشر يه علوم آب و خاك (علوم و فنون كشاورزى و منابع طبيعى) / سال بيست و سه / شماره دوم / تابستان لهه|
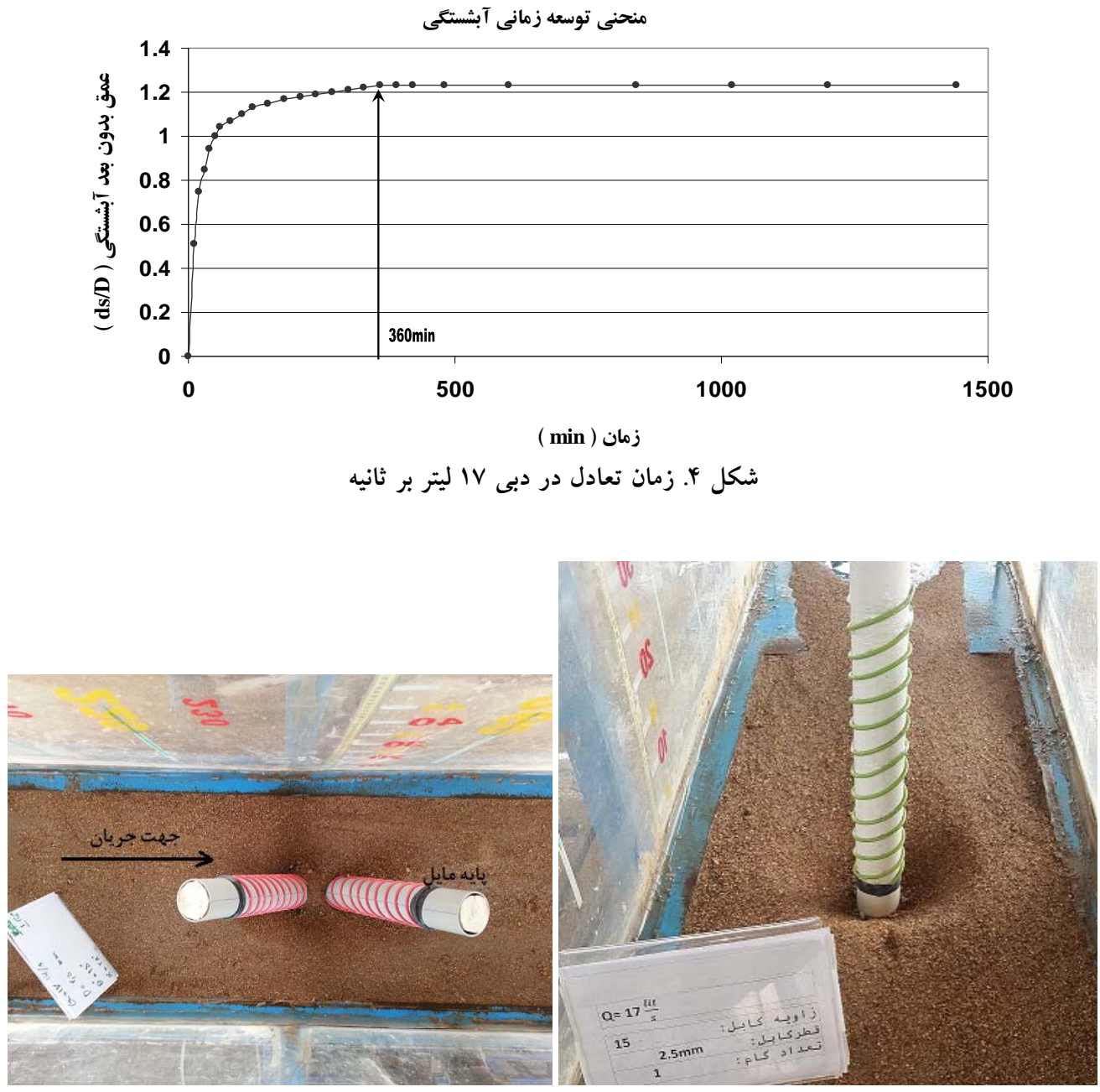

شكل ه. آبشستخى در اطراف گروه بايه مايل و بايه عمودى بعد از آزمايش

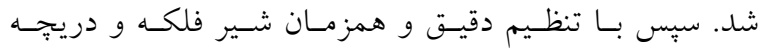
ياييندست عمق جريان •ا سانتى متر و دبى مورد نظر حاصل

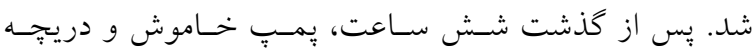
انتهايى بسته شد تا آب موجود در كانال بهآرامى زهكشى شــ

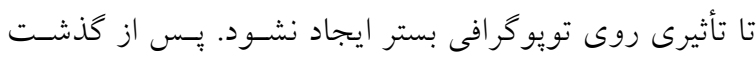
جند ساعت و تخليه كامل آب از درون كانال، بهوسـيله عمـق سنج ليزرى با دقت ميلىمتر، تويوگر افى بستر در اطـراف يايسه برداشت شد. بهمنظور بررسى دقيـق تغييـرات ايجـاد شــده در بستر در امتداد عرضى فاصله نقاط برداشت دو سانتى متر و در امتداد طولى با توجه به موقعيت دو سـانتى متر در نظـر گرفتسه شد (شكل ه). ابتداى ورودىى فلوم اندازه گيرى شد. در ابتــاى هـر آزمـايش يايهها بهصورت جداكانه در فاصله شش مترى از ابتداى فلوم

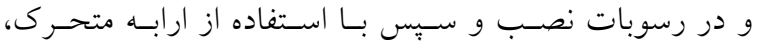
رسوبات بستر كانال تحت شيب ثابـت مسـطح شـد. يسيش از

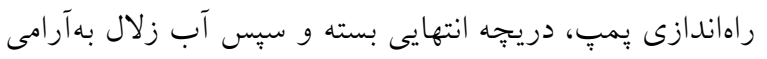
به درون كانال هدايت شد تا از ايجـاد ريبـل و نـاهموارى در سطح بستر جلو گيرى شود. مدت زمان اشباع كانال بين م ب تـا هـ دقيقه بود. يس از بالا آمدن آب و اطمينان از مرطوب شدن

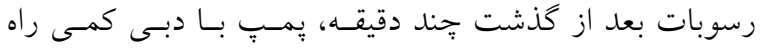
اندازى شد و بــهآرامسى توسـط شـير فلكسه اصسلى روى لولـه ورودى به حوضجه آرامش، دبى بهميـزان مـورد نظـر رسـانده 
و در نتيجه باعـث كـاهش تـوان حمـل رسهوب بـار بسـتر بـهـ

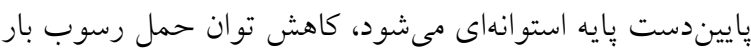

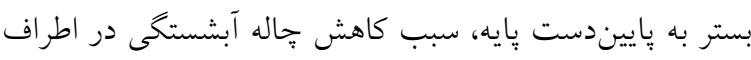

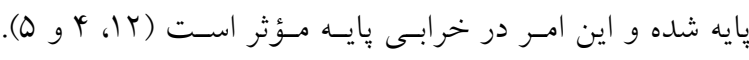
جدول (1) درصد كاهش عمق آبشستخى نسبى در اطـراف بايـهـ

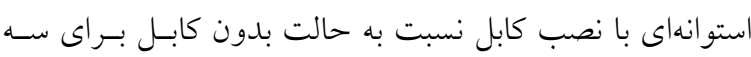

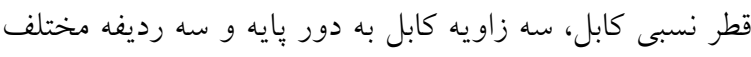

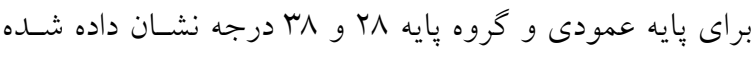

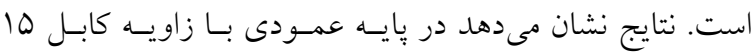

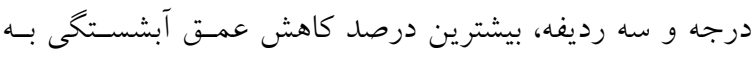

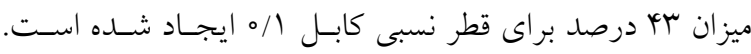

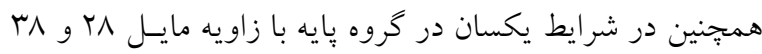

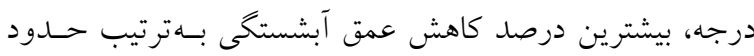

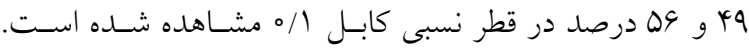

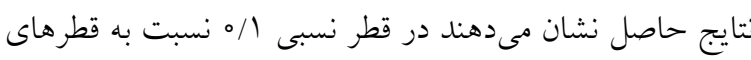
ديخر كابل، بيشترين درصد كاهش در عمق آبشسـتخى در كليسه

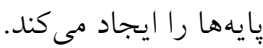
بهمنظور مقايسه تأثير قطر نسبى كابل بر عمق آبشستخى نسبى

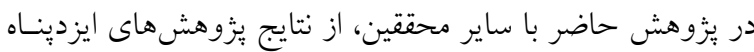

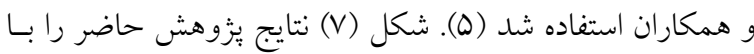
نتايج ايزديناه و همكاران در سه زاويه كابـل ها، مبا و ها درجسه

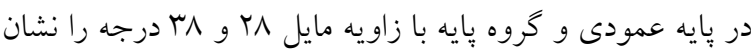

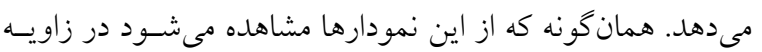
مختلف قراركيرى كابل در اطراف بايه عمودى و كروه بِيهها، بـا لـا

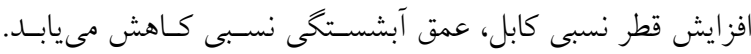

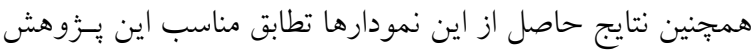
با بززوهش هاى محققين ديخر را نشان مىدهد.

\section{تأثير زاويه مايل گروه يايهها بر عمق آبشستخى}

شكل (^) نمودار بدون بعد عمق آبشستخى نسبى و زاويه مايسل

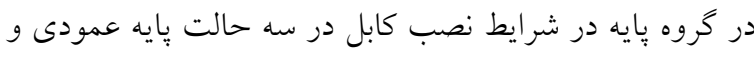

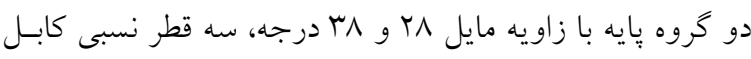

\section{بحث و نتايج}

در همه آزمايشها يس از تنظيم دبى و عمق جريـان، بلافاصسله

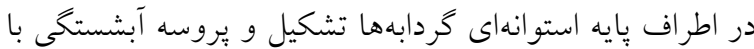

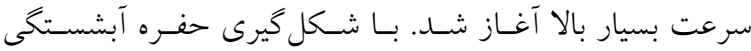
رسوبها برخاسته از حفره به سمت ياييندست منتقـل شـدند.

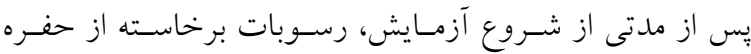

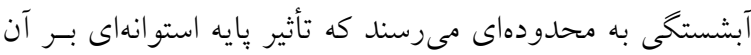

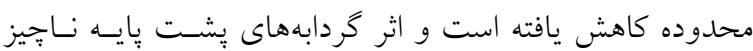

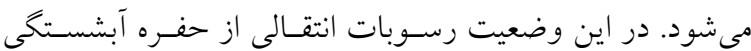

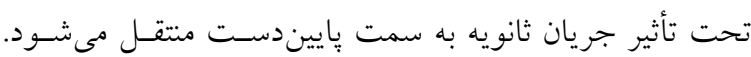

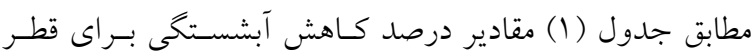
نسبى، زاويه و تعداد رديف كابل مختلف محاسبه شد.

\section{تأثير قطر نسبى كابل بر عمق آبشستخى}

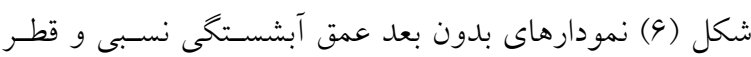
نسبى كابل در اطراف پايه استوانهاى در شرايط عدم نصب و بـاــا

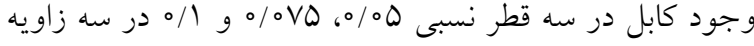

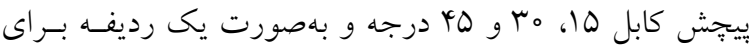

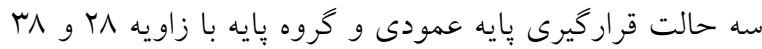
درجه بلصورت عمود بر مسير جريان نشان مىدهد. همانكونسه كه در اشكال مشاهده مىشود در كليه شرايط، نصـب كابـل بـهـ دور پايه استوانهاى عامل مـؤثر در كـاهش عمـق آبشستــى در

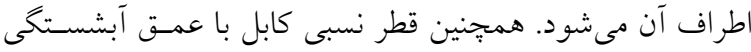
نسبت عكس دارد و با افزايش قطر نسبى كابل در اطـراف يايـهـ استوانهاى در كليـه شـر ايط باعـث كـاهش عمـق آبشسـتخى در

$$
\text { اطراف يايه استوانهاى مىشود. }
$$

وجود بايه در مسير جريان باعث تشكيل جريانهاى گردابى در اطراف آن شده و اين جريانهاى مكانيسم اصسلى آبشستـى لئى

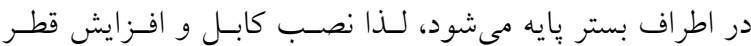
نسبى كابل آن در اطراف يايه، باعث افزايش زبرى در بدنه يايسه و بالابردن مقاومت آن در برابر تنش برشى ناشسى از جريـان و

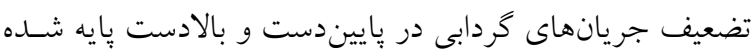


نشر يه علوم آب و خاك (علوم و فنون كشاورزى و منابع طبيعى) / سال بيست و سه / شماره دوم / تابستان لهه|

جدول ا. مشخصات كابل و آبشستخى مربوط به پِايه عمودى و گروه پايهها

\begin{tabular}{|c|c|c|c|c|c|c|}
\hline در حرد كاهش آبشستى & 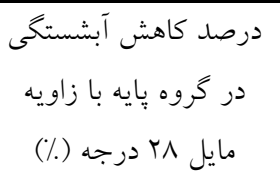 & 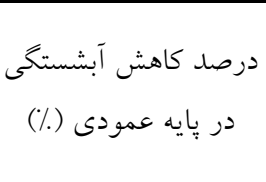 & رديف & كابل زاويه يِيجش & قطر نسبى كابل & رديف \\
\hline rq & TQ & rI & يك رديفه & 10 & $\circ / \circ \Delta \circ$ & 1 \\
\hline ra & ro & ro & دو رديفه & 10 & $\circ / 000$ & r \\
\hline$\psi \wedge$ & H & rی & سه رديفه & 10 & $\circ / \circ \Delta \circ$ & $r$ \\
\hline ro & m & TV & يك رديفه & 10 & $\%$ VV & r \\
\hline 49 & $\varphi_{0}$ & re & دو رديفه & 10 & $\%$ VVO & 0 \\
\hline$\Delta Y$ & 49 & pr & سه رديفه & 10 & $\circ / \circ \Delta$ & 9 \\
\hline kr & rv & rr & يك رديفه & 10 & $\circ / 100$ & v \\
\hline 49 & $\mu t$ & rq & دو رديفه & 10 & $\circ / 10$ & $\wedge$ \\
\hline$\Delta \varphi$ & 49 & kr & سه رديفه & 10 & $\circ / 100$ & 9 \\
\hline r & 19 & 19 & يك رديفه & $r_{0}$ & $\circ / \circ \Delta \circ$ & 10 \\
\hline rq & ro & rI & دو رديفه & $r_{0}$ & $\circ / 0 \Delta \circ$ & 11 \\
\hline rV & rT & rA & سه رديفه & r。 & $\circ / 0 \Delta$. & Ir \\
\hline YA & YY & $r_{0}$ & يك رديفه & $r_{0}$ & $\%$ $/ 0$ & 14 \\
\hline rq & ro & ro & دو رديفه & $r_{0}$ & $\circ / \circ Q$ & 14 \\
\hline rr & r & r & سه رديفه & $r_{0}$ & $\%$ VO & 10 \\
\hline rV & ry & 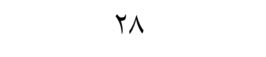 & يك رديفه & $r_{0}$ & $\circ / 100$ & 19 \\
\hline$\uparrow \wedge$ & r & rی & دو رديفه & $r_{0}$ & $0 / 100$ & IV \\
\hline$\Delta r$ & 49 & 4 & سه رديفه & $r_{0}$ & $0 / 100$ & 11 \\
\hline Tr & 11 & 14 & يك رديفه & 10 & $\circ / 000$ & 19 \\
\hline TV & r & TY & دو رديفه & ia & $\circ / 0 \Delta \circ$ & $r_{0}$ \\
\hline r & rq & זس & سه رديفه & 10 & $\circ / 000$ & rI \\
\hline TV & r & 19 & يك رديفه & ia & $\%$ VO & Tr \\
\hline rV & rr & 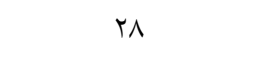 & دو رديفه & is & $\%$ VVO & rr \\
\hline 41 & rq & r & سه رديفه & 40 & \% VQ & TY \\
\hline rV & ry & $r \Lambda$ & يك رديفه & 10 & $0 / 100$ & ro \\
\hline 49 & $\varphi_{0}$ & rq & دو رديفه & ro & $\circ / 100$ & rq \\
\hline 01 & iQ & ro & سه رديفه & id & $\circ / 100$ & TV \\
\hline
\end{tabular}

نسبت عكس دارد و در كليه شـرايط نصـب كابـل بـا قطرهـاى

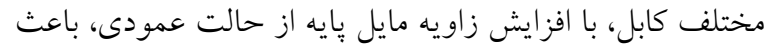

كاهش عمق آبشستخى در اطر اف بايهها مى شود. انحراف بِايه از

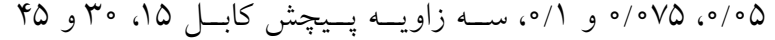
درجه و براى شرايط يكى رديفه نشان مىدهد. همانكونه كـه در

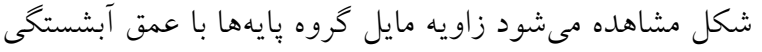



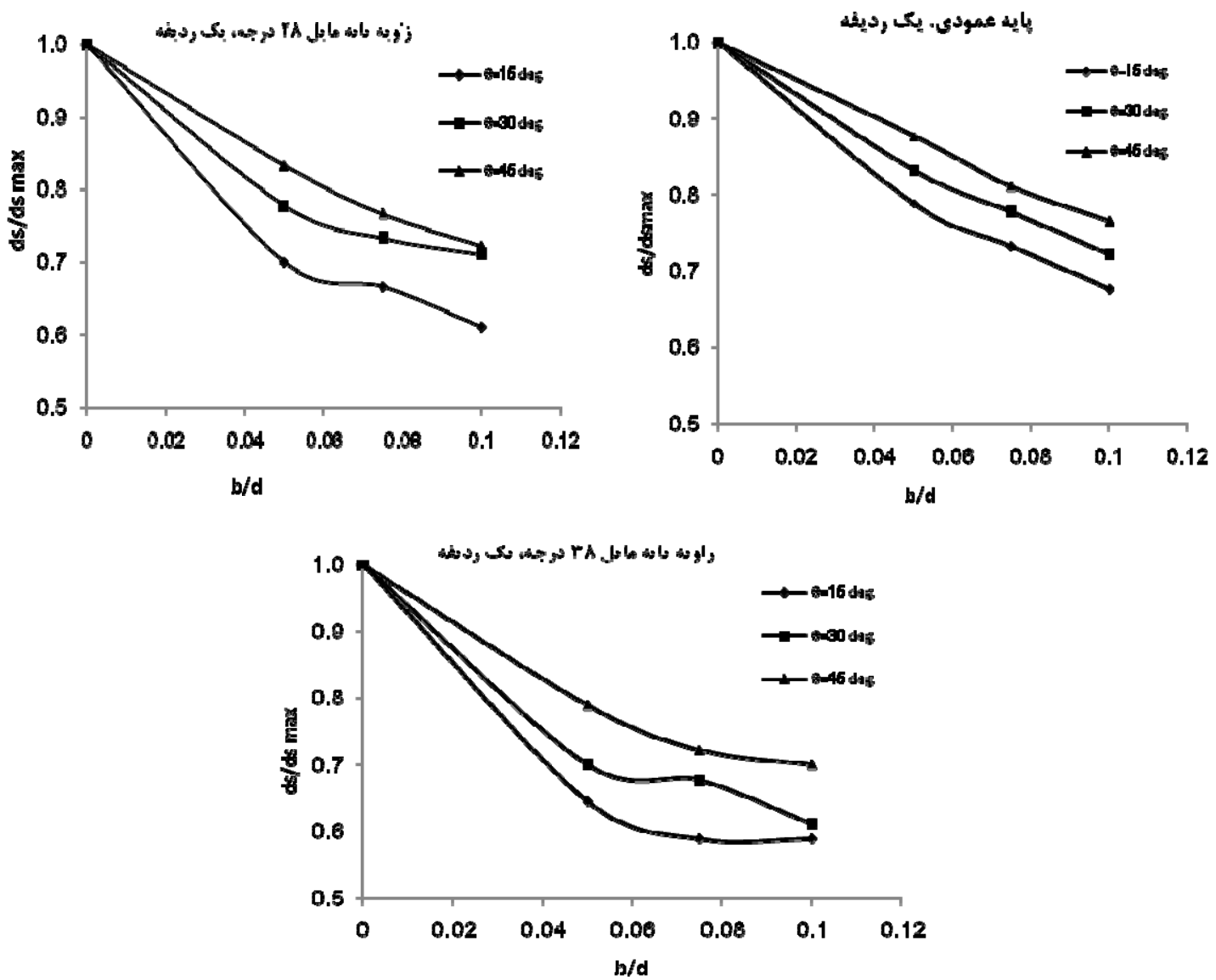

شكل צ. تأثير قطر نسبى كابل بر عمق آبشستى در زاويه مختلف كابل و در سه زاويه يِّش كابل و بهصورت يك رديفه
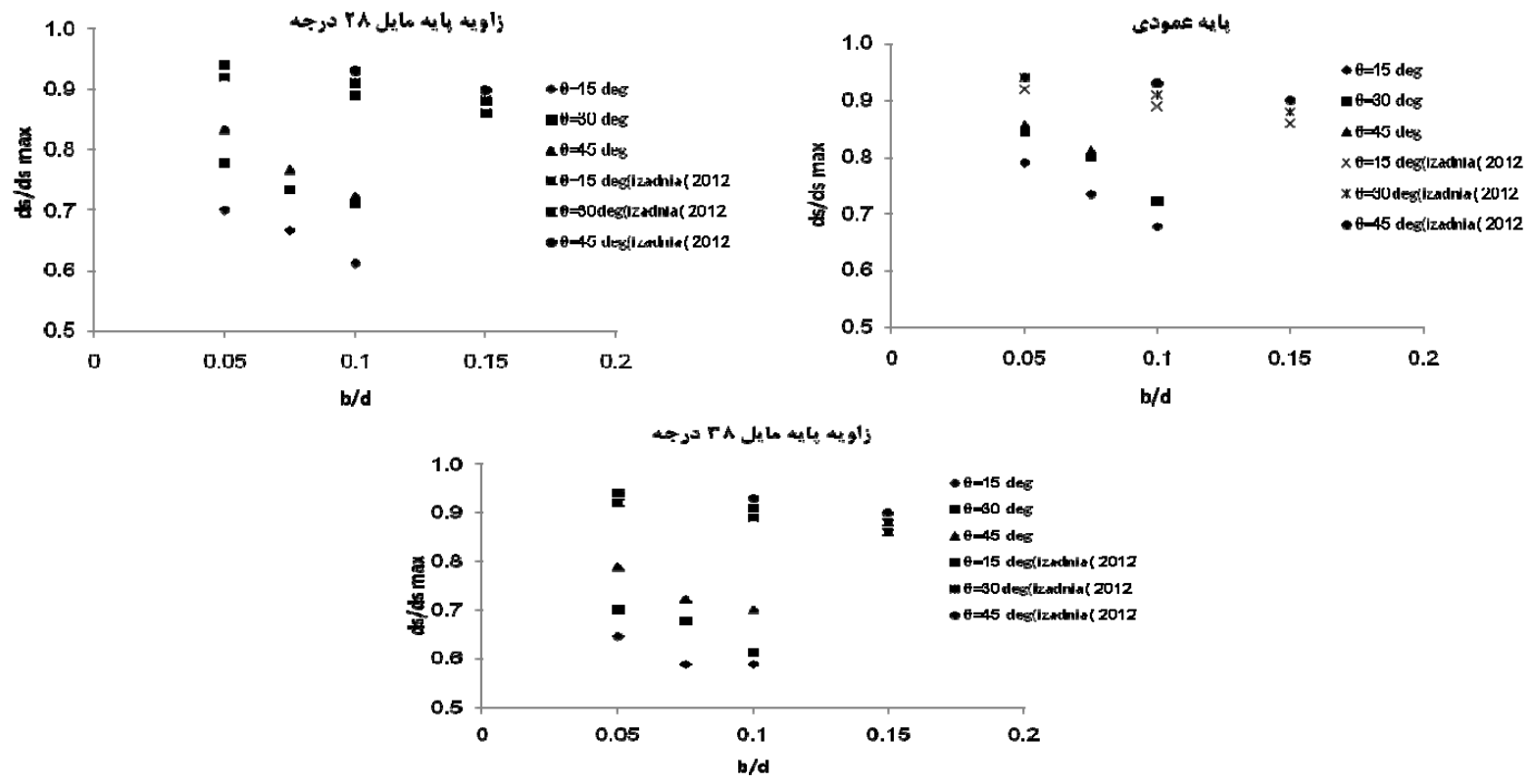

شكل V. مقايسه نتايج يزوهش حاضر با نتايج ايزديناه و همكاران 
نشر يه علوم آب و خاك (علوم و فنون كشاورزى و منابع طبيعى) / سال بيست و سه / شماره دوم / تابستان \هبا
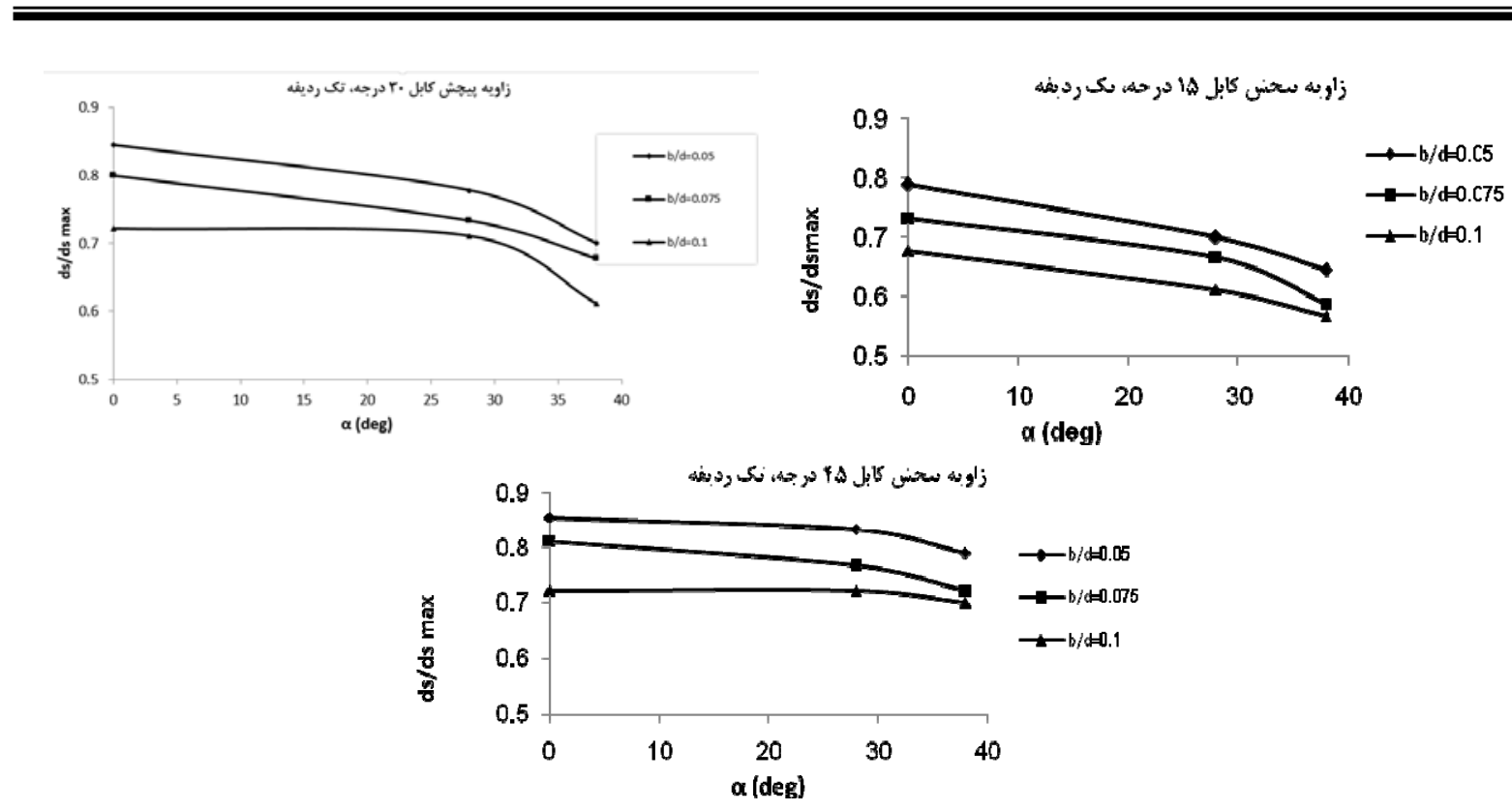

شكل ^^ تأثير زاويه انحراف گروه پايهها بر عمق آبشستگى در سه قطر نسبى كابل و سه زاويه بيجش كابل براى شرايط يك رديفه

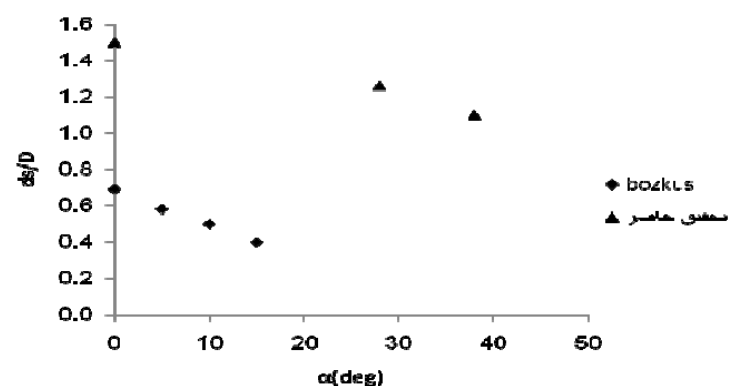

شكل 9.

شكل (9) زاويه مايل در پايه استوانهاى در حالت بدون كابل در مقايسه با نتايج بوزكوز و همكاران را نشان مىدهد. همان كونسه كه از اين نمودار مشاهده مىشود با افزايش زاويه مايـل زيايسه از

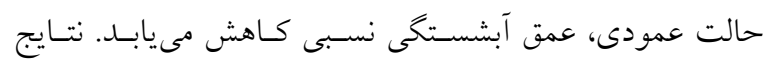

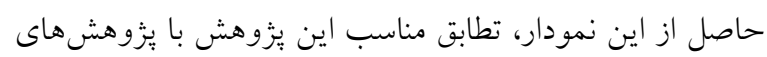
محققين ديخر را نشان مىدهد.

\section{تأثير زاويه بِيجش كابل بر عمت آبشستخى}

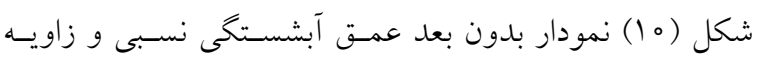

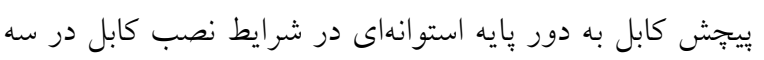

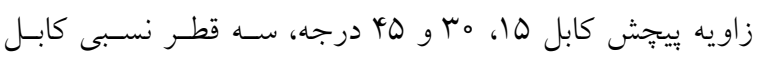

حالت قائم باعث تضعيف قدرت جريانهاى گردابى در اطـراف يايه شده كه در نتيجه باعث كاهش عمق آبشستـى در اطـراف يايه مىشود. مطابق جدول (1) در زاويه كابل 10 درجسه و سـه رديفه بيشترين درصد كاهش عمق آبشستخى در بايه عمـودى و

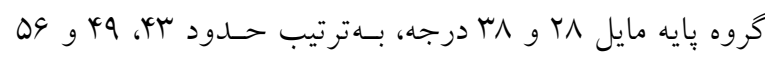
درصد در قطر نسبى كابل / /ه مشاهده شده اسـت. بنـابراين در شرايط يكسان بيشترين درصد كاهش عمق آبشستخى در كـروه يايه مايل ^ه درجه در حدود צه درصد بهدست آمد. بــمنظور مقايسـه تـأثير زاويـهـ مايسل خـروه يايسه بــر عمـق آبشستكى نسبى در يزوهش حاضر با سـاير محققسين، از نتـايج

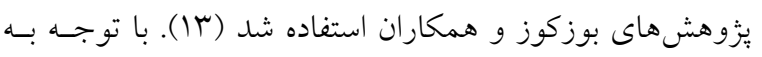



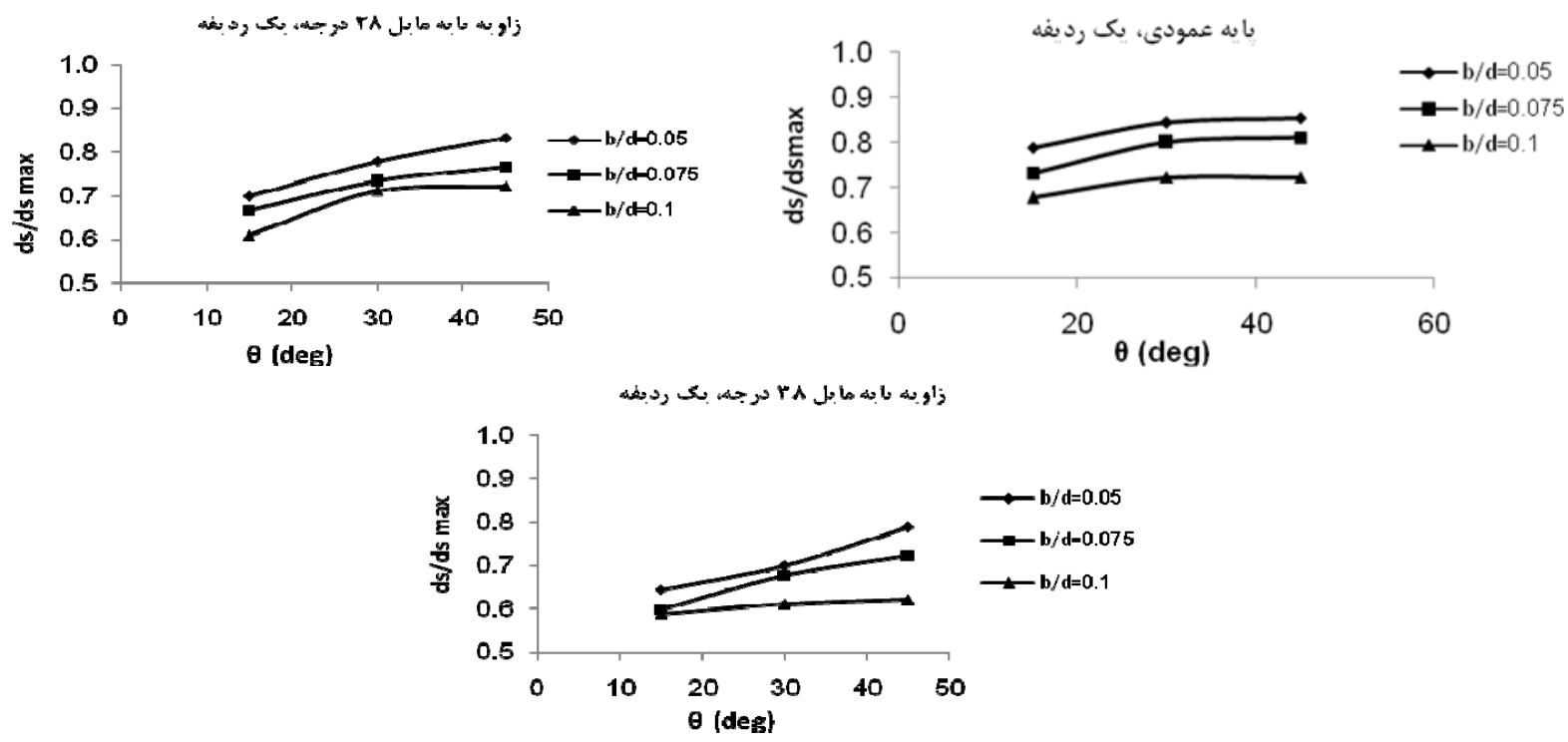

شكل ه ا. تأثير زاويه بيجڤش كابل به دور بِايه بر عمق آبشستحى در سه قطر نسبى كابل و بهصورت يكى رديفه

بيشترين درصد كاهش عمق آبشستخى بهترتيب و4، و4 و ه\& و

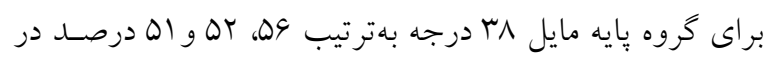
قطر نسبى كابل //ه مشاهده شده اسـت. لـذا بيشـترين درصــ كاهش عمق آبشستخى در پايه عمودى و گـروه يايسهها در قطر نسبى // و در شرايط سه رديفه و در زاويه ها درجه بهترتيب

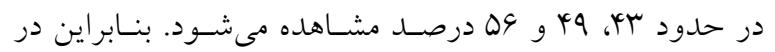
اسـتفاده از كابـل بهتـــ اسـت از زاويــه كمتـر بـهمنظور كـاهش آبشستخى در اطراف بايه استفاده شود.

تأثير تعداد رديف كابل به دور پايه بر عمت آبشستكى شكل (11) نمودار بدون بعد عمـق آبشستـى نسـبى و تعـداد

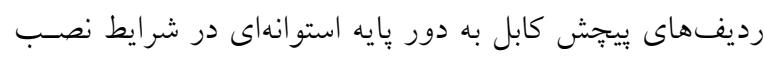
كابل در سه رديف يك، دو و سه دور با سـه قطـر نسـبى كابـل ه॰

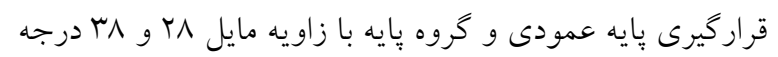
عمود بر مسير جريان نشان مسىدهـد. همان كونسه كـه در شكل

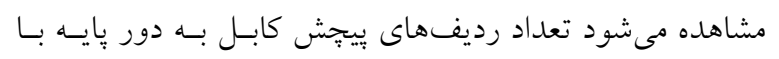
عمق آبشستگى نسبت عكس دارد و در كليه شرايط نصب كابل،

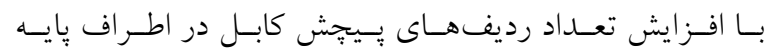

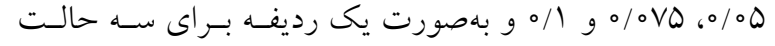

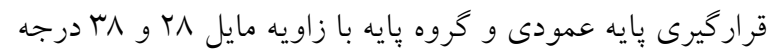
عمود بر مسير جريان نشان مىدهـد. همانكونـه كـه در اشـكال

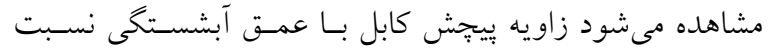
مستقيم دارد و در كليه شرايط نصب كابل با قطرهـاى مختلـف كابل، با افزايش زاويه بيّشش كابل در اطراف بايه استوانهاى در

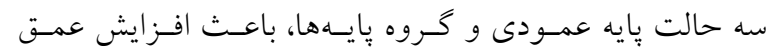
آبشستخى در اطراف بايهها مىشود. از آنجايى كه وجود بايه در مسير جريان باعث تشـكيل جريانهـاى گردابسى در اطـراف آن شده و اين جريانها مكانيسم اصلى آبشستخى در اطـراف بسـتر

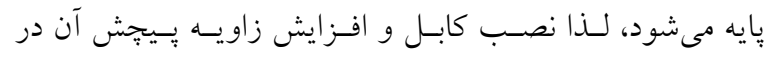
اطراف يايه، باعث وجود مانع و تغيير ناگهانى در مسـير جريـان شده و در نتيجه جريانهاى گردابى در باييندسـت و بالادسـت يايه قوىتر شده و در نتيجه باعث افزايش تـوان حمـل رسـوب

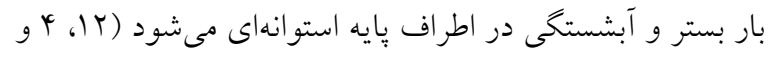

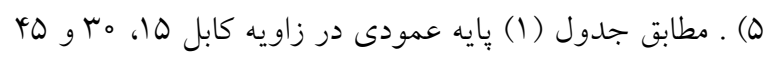
درجه و سه رديفـه بيشـترين درصـد كـاهش عمـق آبشستكى،

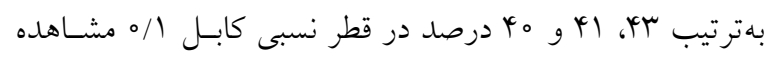

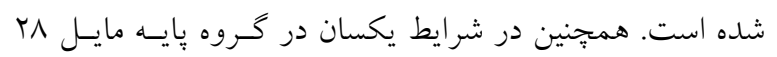


نشر يه علوم آب و خاك (علوم و فنون كشاورزى و منابع طبيعى) / سال بيست و سه / شماره دوم / تابستان لهه|

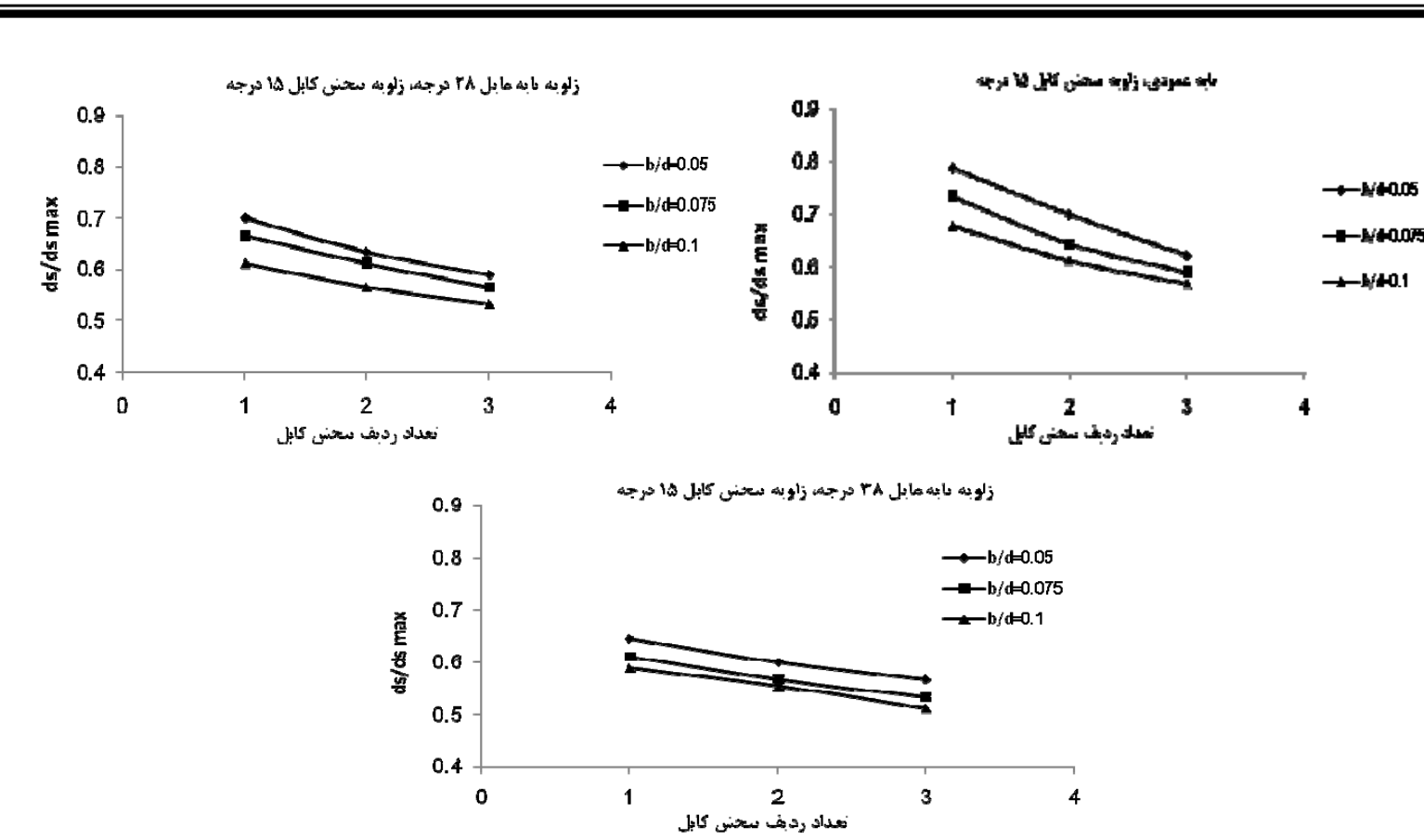

شكل 11. تأثير تعداد رديف بيجش كابل به دور پايه بر عمق آبشستخى در سه رديف يك، دو و سه دور با سه قطر نسبى كابل در زاويه بيجش 10 درجه

استوانهاى، عمق آبشستخى نسبى كاهش مى يابد. از آنجايى كه درصد مشاهده مىشود. وجود يايه در مسير جريان باعث تشكيل جريانهـاى گردابسى

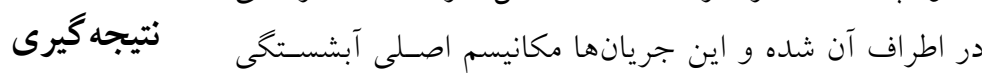

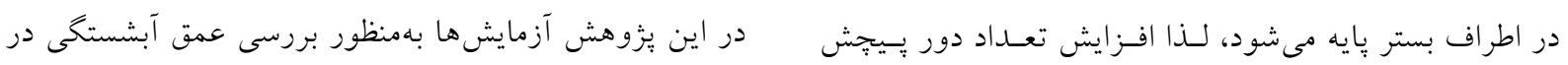

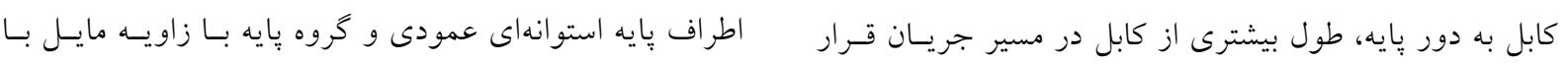

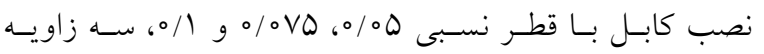
كرفته و در نتيجه باعث تضعيف جريانهاى كردابى و كـاهش

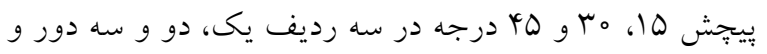
مقايسه آن با حالت بدون كابل در مسير مستقيم با دبى ل ليتر

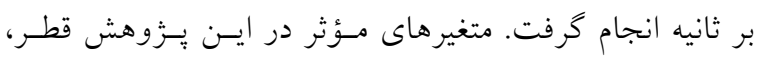
زاويه يِيجش و تعداد رديف كابل در دو نـوع بايـهـ عمـودى و

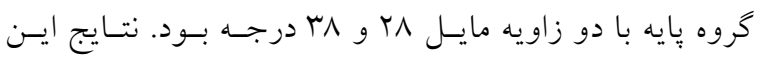
يزوهش نشان داد نصب كابل بـا قطر نسبى / /ه نسـبت بـه قطرهاى ديخر كابل بيشترين درصد كاهش در عمق آبشستخى ستر در كليه يايهها را ايجاد مىكنـد. در شـرايط يكسـان بيشـترين

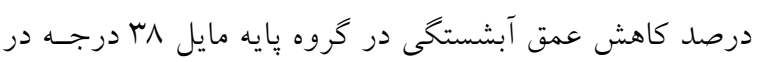
حدود وها درصد بهدست آمل. بيشترين درصسد كـاهش عمـق

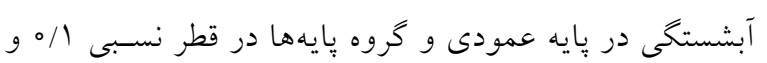

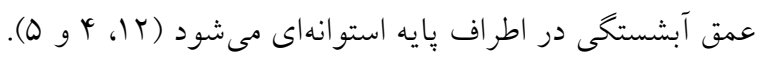
مطابق جدول (1) يايه عمودى در زاويه كابل ها درجه و براى

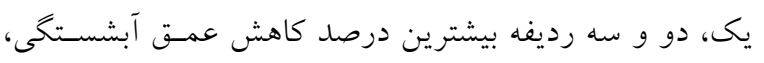

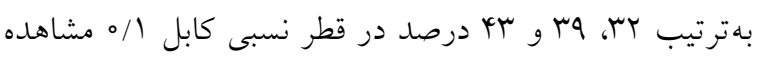
شده است. همجنين در شرايط يكسان در كروه بايسه مايسل بـا

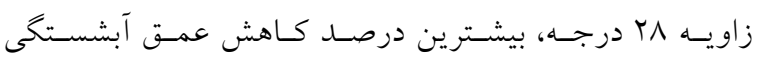

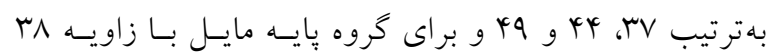

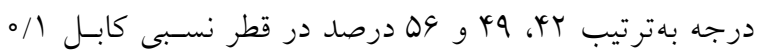

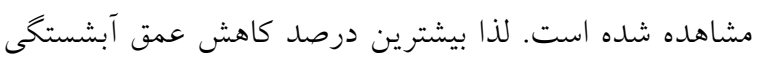

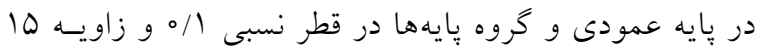

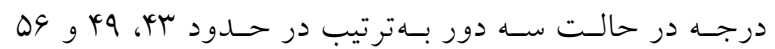




$$
\begin{aligned}
& \text { در شرايط سه رديفه و در زاويه ها درجه بهترتيب در حسدود سياسگزارى } \\
& \text { از مساعدت مسئولين محترم دانشخاه آزاد اسلامى واحسـد اهـواز } \\
& \text { سץ، } \\
& \text { بهمنظور قرار دادن امكانات، تسهيلات و كمكهاى مالى در اين } \\
& \text { و سه رديفه بيشترين درصد كاهش عمق آبشستشى در گــروه } \\
& \text { يزووهش تشكر و قدردانى مى شود. }
\end{aligned}
$$

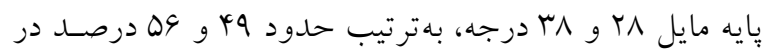

$$
\begin{aligned}
& \text { قطر نسبى كابل // مشاهده شده است. }
\end{aligned}
$$

\section{منابع مورد استفاده}

1. Aghli, M. and M. Zomorodian. 2013. Effect of collar and cable on the depth of scouring around the bridge at the river bend. Iranian Journal Irrigation Science and Engineering (Agricultural Science Journal) 36(3): 31-40. (In Farsi).

2. Breusers H. N. C., G. Nicollet and H. W. Shen. 1977. Local scour around cylindrical piers. Journal of Hydraulic Research, IAHR 15(3): 211-252.

3. Chiew, Y. M. and B. W. Melville. 1987. Local scour around bridge piers. Journal of Hydraulic Research 25(1):15-26.

4. Dey, S., B. M. Sumer and J. Fredsoe. 2006. Control of scour at vertical circular piles under waves and current. Journal of Hydraulic Engineering 132: 270-279.

5. Izadinia, E. and M. Heidarpour. 2012. Simultaneous use of cable and collar to prevent local scouring around bridge pier. International Journal Sediment Research 27(2012): 394-401.

6. Khwairakpam, P. and A. Mazumdar. 2009. Local scour around h draulic structures. International Journal of Recent Trends in Engineering 1(6): 59-61.

7. Melville, B. W. and Y. M. Chiew. 1999. Time scale for local scour depth at bridge piers. Journal of Hydraulic Engineering, ASCE 125(1): 59-65.

8. Oliveto, G. and W. H. Hager. 2002. Temporal evolution of clear-water pier and abutment scour. Journal of Hydraulic Engineering, ASCE 128(9): 811-820.

9. Quazi, M. E. and A. W. Peterson. 1973. A method for bridge pier riprap design. In: Proceedings of the First Canadian Hydraulics Conference, CSCE, Edmonton, AB, PP: 96-106.

10. Raudkivi, A. J. 1998. Loose boundary hydraulics. $4^{\text {th }}$ Edition. Rotterdam; Brookfield, VT: Balkema.

11. Raudkivi, A. J. and R. Ettema. 1983. Clear-water scour at cylindrical piers. Journal of Hydraulic Engineering, ASCE 109(3): 338-350.

12. Zomorodian, M. and M. Aghili. 2014. Effect of collar and cable on the depth of scouring around the group bridge at the river bend. Iranian Journal of Soil and Water Research 45(1): 1-10.

13. Zafer Bozkus, Z. and M. Murat Cesme. 2010. Reduction of scouring depth by using inclined piers, Canada Journal Civil Engineering 37: 1621-1630. 


\title{
Investigation of the Effect of Cable on the Control of Scour around the Piles Group in the River
}

\author{
H. Davodi ${ }^{1,2}$, A. R. Masjedi² ${ }^{*}$ M. Heidarneja ${ }^{2}$, A. Bordbar ${ }^{2}$ and A. A. Kamanbedast ${ }^{2}$
}

(Received: January 21-2018 ; Accepted: May 27-2018)

\begin{abstract}
In this study, some experiments were carried out in a rectangular plexiglass flume to study the effect of the cable around a vertical tripod and two piles groups with different angles. In this research, a series of experiments were performed by placing a cylindrical vertical pileand two piles groups with different angles separately in two modes including with cable and without cable. The experiments were carried out using three types of cable with various diameters, number of threads and thread angles at a constant discharge in clear water. In each experiment, scour depth at the end of the test was measured; then, the scour depth was calculated in different conditions using the obtained data. The best configuration in the vertical pier and piers group was found for the cable-pier diameter ratio of 0.1 , the thread angle of $15^{\circ}$ and the triple threads. The result indicated that the scour reduction was enhanced as the cable diameter and threads were increased and the thread angle was decreased. So in the piers group of 28 and $38^{\circ}$, scour depth was reduced to about 43, 49 and 56\%.
\end{abstract}

Keywords: Cable, Scour depth, Piles group, Sediment

1. Department of Water Science and Engineering, Khouzestan Science and Research Branch, Islamic Azad University, Ahvaz, Iran.

2. Department of Water Science and Engineering, Ahvaz Branch, Islamic Azad University, Ahvaz, Iran.

*: Corresponding Author, Email: drmasjedi.2007@yahoo.com 